\title{
Design and Manufacturing of Single Sloped Solar Still: Study the Effect of Inclination Angle and Water Depth on Still Performance
}

\author{
Ali A. Aljubouri \\ Department of Applied Sciences, Applied Sciences Researches Unit, University of \\ Technology, Baghdad-Iraq. \\ Corresponding Author: ajubouri1@ yahoo.com
}

\begin{abstract}
The most prominent factors that have a significant influence on the performance of solar distillation are the inclination angle of the solar still cover and the water depth within the still basin. This paper was investigated an experimental performance of a single solar still. Five single sloped solar stills were designed and fabricated to operate under Baghdad city weather condition during August 2016. The inner dimensions of each basin were $0.5 \times 0.5 \mathrm{~m}$. The glass covers were tilted at $20^{\circ}, 31^{\circ}, 45^{\circ}$ and $50^{\circ}$ with respect to the horizontal. The temperatures of the outer glass covers surfaces were measured. Also, this study presents an experimental investigation on the potable water collection amount with the water depths of $1,2,3,5$, and $7 \mathrm{~cm}$ into each still basin and the different glass lid inclination angles. The hourly amount of extracted drinkable water was monitored. The daily produced amounts of fresh water increased by reducing the tilt angle from $50^{\circ}$ to $20^{\circ}$, and diminish of water depth in the basin from $7 \mathrm{~cm}$ to $1 \mathrm{~cm}$. The highest total daily amount was $495 \mathrm{ml} /$ day $\left(\sim 21 / \mathrm{m}^{2} /\right.$ day $)$ for solar still with tilt angle of $20^{\circ}$ and water depth of $1 \mathrm{~cm}$.
\end{abstract}

[DOI: $\underline{10.22401 / \mathrm{JNUS} .20 .2 .08]}$

Keywords: Single Sloped Solar Still, water depth, Inclination Angle, Still performance.

\section{Introduction}

Water is one of the most important necessities of life, where life is impossible without water. Due to the rapid global development in the industrial and agricultural fields, as well as to the dramatic population growth, the request of potable water all over the world is increasing and become an urgent necessity [1].

As it is known to all that our country and most of the Arab countries enjoying a sunny atmosphere most days of the year. Since the desert represents most of the area of these countries, as well as, there are many small communities in the hinterlands. Therefore the above mentioned reasons making fresh water delivery process to such areas are semiimpossible because of the high implementation cost of such a project. Hence, the use of solar distillation is considered the ideal solution to get fresh drinking water especially that the solar energy used in this technique is renewable and free.

Solar desalination has been extensively grown in many countries because of inadequate fresh water resources in these countries. The main challenge of this century is the improving of the performance and the efficiency of water purification technology to produce drinking water [2]. Therefore; many researches were carried out to overcome this crisis with protection of the available limited freshwater supplies and developing new techniques to purify brackish and sea water by the use of solar energy

Solar stills are classified into two kinds, active and passive stills. Active still uses an external thermal energy source added to the solar energy to heat the water in the still [3]. In passive stills, only the solar energy falling into the solar still structure [4]. Single slope solar still is widely used in solar desalination due to its simple design, and low operation and maintenance costs. The only maintenance required is the cleaning of the basin and glass cover, but the productivity of the solar stills is low.

In general, the solar still is consists of some major components such as a basin, a transparent cover (glass or plastic), a distillate outlet channel. Other components may be added to the previous components such as; insulation, which is fixed under or/ and around the basin sides, sealants, piping and valves, 
and outer or internal reflectors to concentrate sunlight [5].

A solar still is constructed of an airtight insulated basin that is covered with a transparent sloped glass cover. The incident solar radiation transmitted through the transparent glass or plastic cover and is absorbed by salty or brackish water in the basin, so that water is heated and gives off water vapor. The water vapor rises to a cooler area and condenses on the inner side of the glass cover. Since the glass is tilted, gravity will cause the condensed water to flow down towards the collection channel to go out of the still to a storage container.

Several theoretical and experimental studies have been carried out on single slope solar stills [6]. There are many factors that affecting on the solar still productivity, such as the environmental temperature[7], the temperature difference between the basin water and the glazing cover [8], materials and thickness of the basin sides insulation $[9,10]$, water depth in the basin [11], wind velocity [12], addition of absorbing materials [13], free surface of water [14], and glass cover inclination angle $[15,16]$.

The aim of this experimental study is to investigate the effect of inclination angle and water depth on the productivity of potable water by solar distillation using five solar stills in passive mode under the Iraqi climate at Baghdad city (longitude $44^{\circ} 422^{\prime}$ E, latitude $33^{\circ} 325^{\prime \prime} \mathrm{N}$ ) in August 2016.

\section{Experimental Work}

Five of single slope solar stills were designed and manufactured from locally available materials; two of them were in same tilted angle but in different basin depth. Five stills were fabricated with the same shape and area, but differ from each other by the inclination angle. The inner dimensions of each basin were $0.5 \times 0.5 \mathrm{~m}$ and the effective area was $0.25 \mathrm{~m}^{2}$. A schematic diagram of a typical single sloped solar still is shown in Fig.(1). All stills are made of $1.5 \mathrm{~mm}$-thick galvanized steel sheet and 4-mm thick window glass cover as a condensing surface. The glass cover of each basin is fixed on the basin body by silicon rubber sealant (which is made strongly contact between the glass and other materials) to prevent or reduce the vapor leakage between the glazing cover and the solar still body. The base of each solar still is painted black to increase the sun heat absorption. For each still basin, the condensed water coming down of the tilted glass cover to interior collection channel and out of a storage container. This channel is made of galvanized steel sheet of (U) shape welded to the lower rectangular side of the basin. Unpurified water is added manually using a rubber tube at 12:00 midnight once a day. To prevent splashing onto the interior of the glass cover or overflowing into the collection channel, the outlet of the rubber tube should be in touch with the basin base, as well as, water should be added at a slow enough flow rate. The technical specifications of the solar stills are illustrated in Table (1).

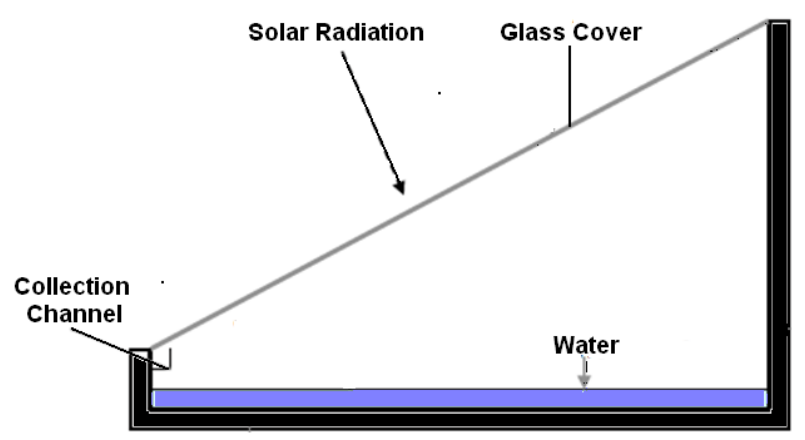

Fig.(1): The schematic diagram of the single slope solar still. 
Table (1)

The technical specifications of the single sloped solar still.

\begin{tabular}{|c||c|c|c|c|c|}
\hline \multirow{2}{*}{ Specifications } & \multicolumn{5}{|c|}{ Dimensions } \\
\cline { 2 - 6 } & SS No.1 & SS No.2 & SS No.3 & SS No.4 & SS No.5 \\
\hline \hline Height (Front Side) $(\mathrm{cm})$ & 10 & 20 & 20 & 20 & 20 \\
\hline Height $($ Back Side) $(\mathrm{cm})$ & 28 & 38 & 50 & 70 & 80 \\
\hline \hline Glass Area $\left(\mathrm{cm}^{2}\right)$ & 2660 & 2660 & 2915 & 3535 & 3900 \\
\hline \hline Tilt Angle $\left({ }^{\mathbf{o}}\right)$ & 20 & 20 & 31 & 45 & 50 \\
\hline
\end{tabular}

SS No.1: Solar Still Number 1; SS No.2: Solar Still Number 2; SS No.3: Solar Still Number 3 SS No.4: Solar Still Number 4; SS No.5: Solar Still Number 5

\section{Results and Discussion}

This experimental study is performed under the weather conditions during August 2016 by using five solar still units.

This section will illustrate the influence of some parameters on the productivity of the solar stills, such as inclination angle, water depth and outer glass led surface temperature. Two variables were measured hourly such as outer glass temperature and productivity.

The effect of glass cover angle variations on the productivity at a certain water depth is shown in Figs. (2-6). These figures illustrate that as the cover inclination angle decreases, the water collection amount increases. Also, these figures present that the collected water increases gradually during the daytime, then it reaches the maximum yield amount at 14:00-
15:00 Pm and then decreases due to decreasing the surrounding ambient temperature until the midnight.

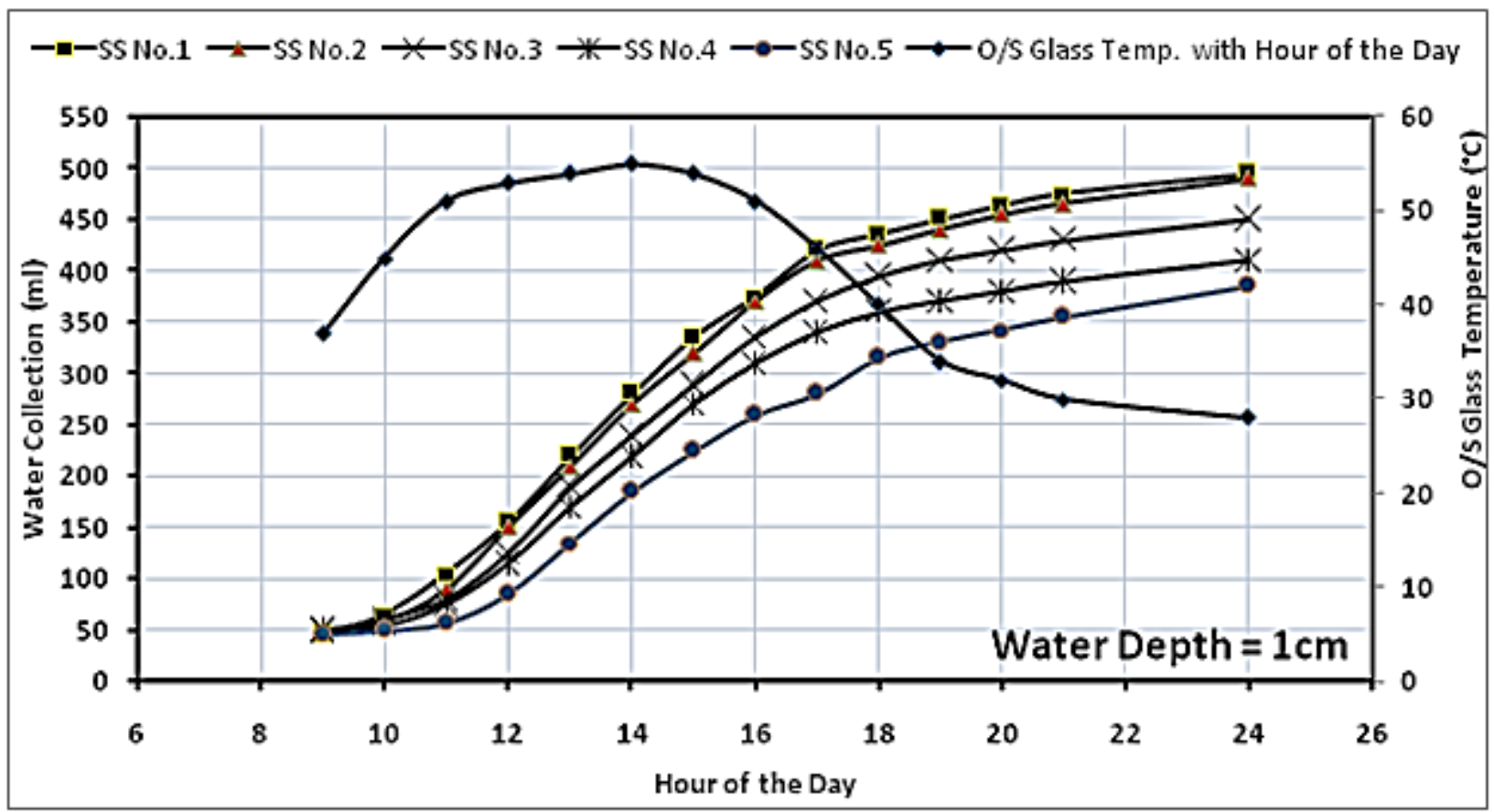

Fig.(2): Time variation of the hourly collected distilled water and outer glass surface temperature for the five single sloped solar stills at water depth of $1 \mathrm{~cm}$. (O/S: outer surface). 


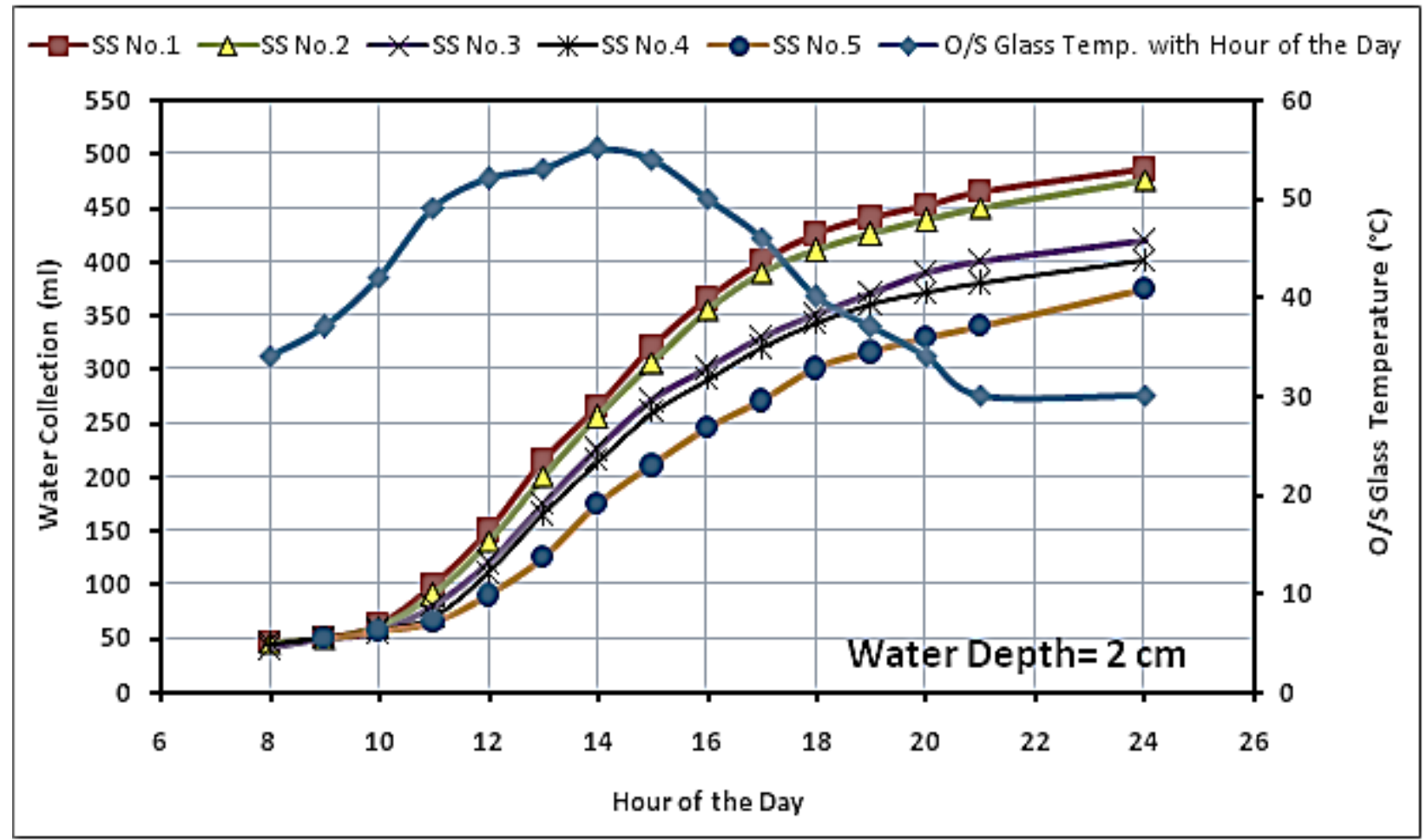

Fig.(3): Time variation of the hourly collected distilled water and outer glass surface temperature for the five single sloped solar stills at water depth of $2 \mathrm{~cm}$. (O/S: outer surface).

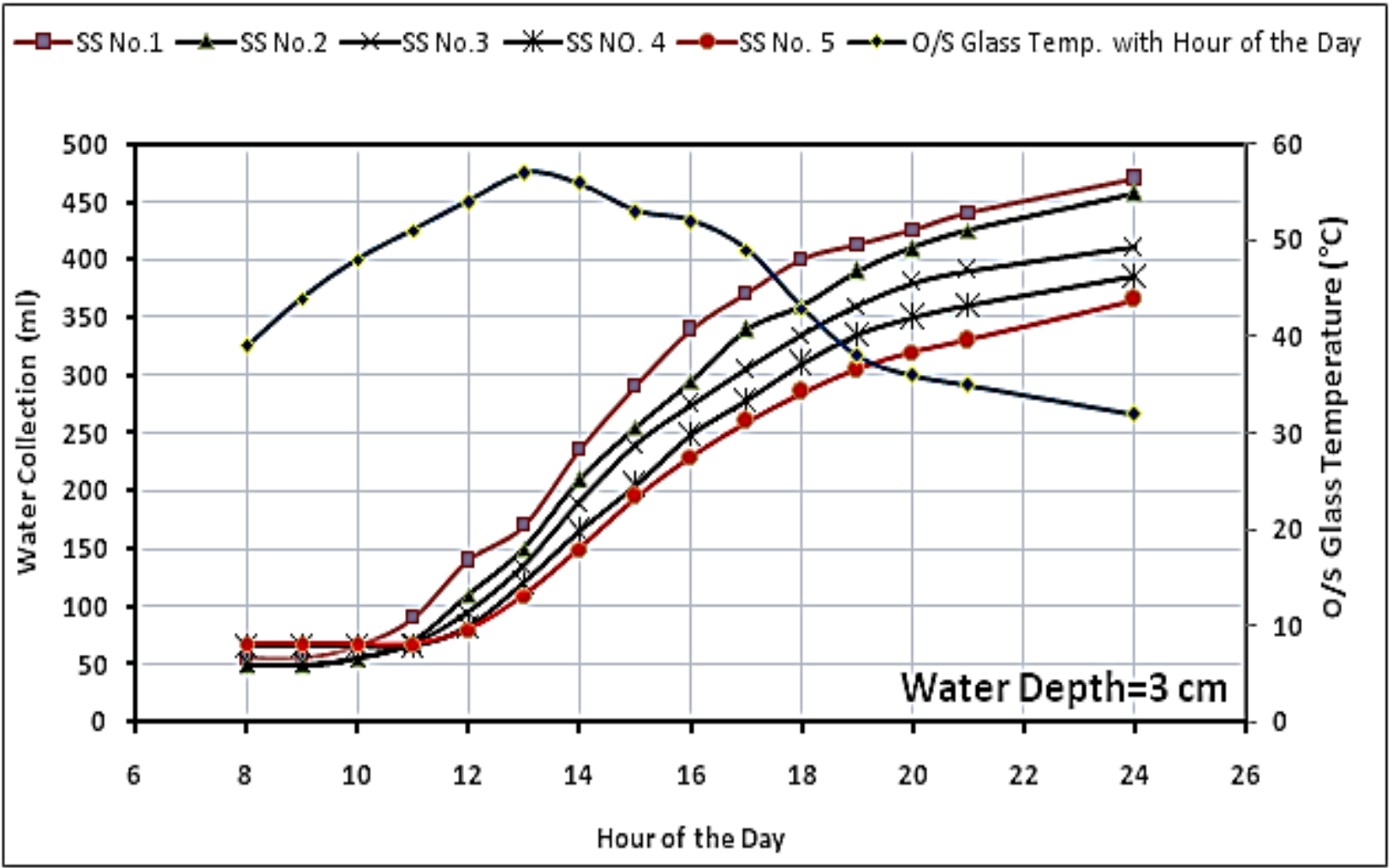

Fig.(4): Time variation of the hourly collected distilled water and outer glass surface temperature for the five single sloped solar stills at water depth of $3 \mathrm{~cm}$. (O/S: outer surface). 


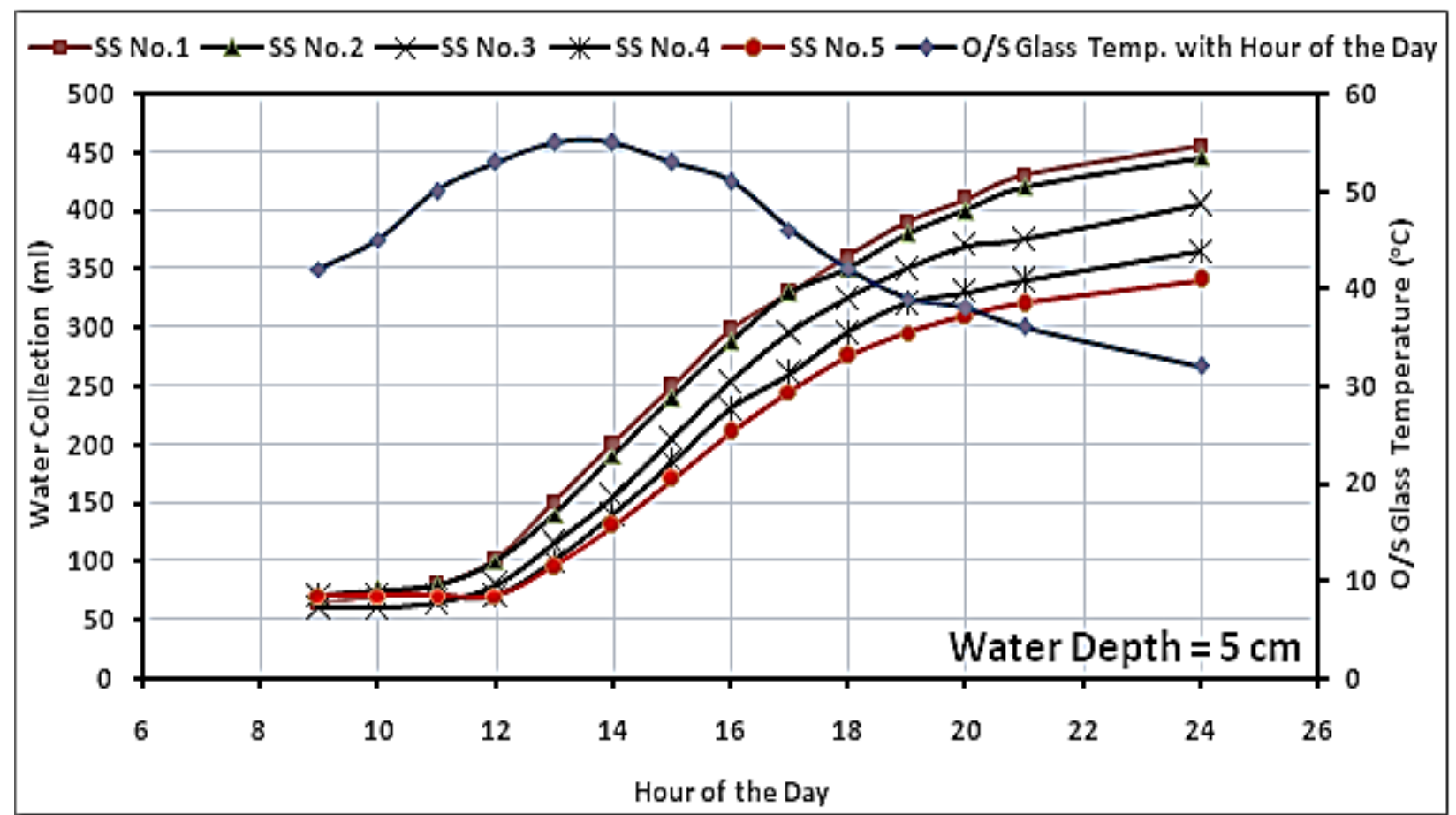

Fig.(5): Time variation of the hourly collected distilled water and outer glass surface temperature for the five single sloped solar stills at water depth of $5 \mathrm{~cm}$. (O/S: outer surface).

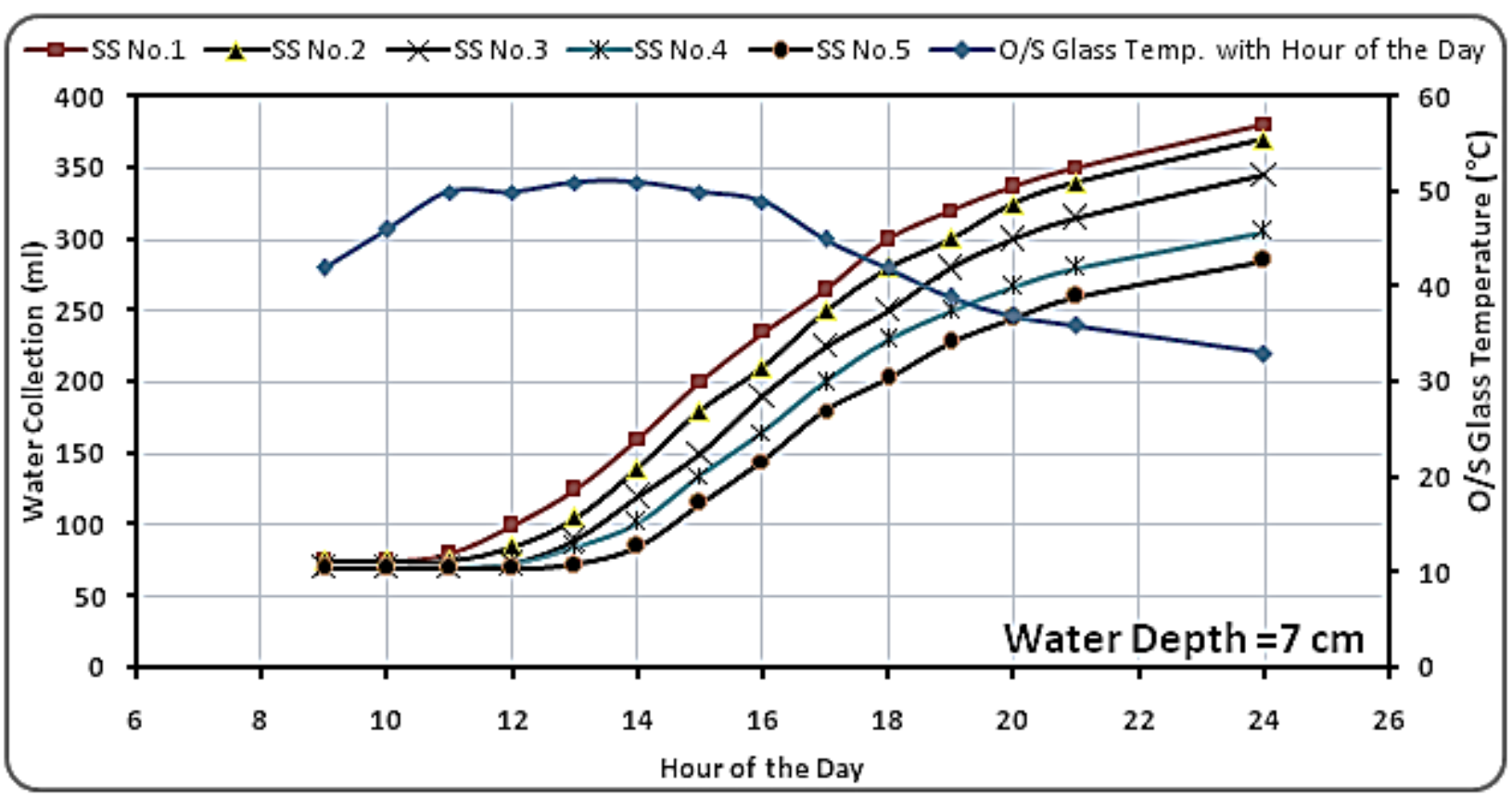

Fig.(6): Time variation of the hourly collected distilled water and outer glass surface temperature for the five single sloped solar stills at water depth of $7 \mathrm{~cm} .(O / S$ : outer surface).

The effect of the glass lid inclination angle on the solar still productivity can introduce several changes in the solar still, such as:

Firstly, change the angle of inclination, leads to change the size of the water vapor above the water surface, where the increase in volume increases the length of time required for the beginning of the production of distilled water. Secondly, increasing tilt angle means more oblique glass surface area, thus increases the loss of thermal energy from the glass cover. Thirdly, in summer season, when the tilt angle decreases, the incident angle of the sun rays approach to the perpendicular angle to the horizontal plane, especially at the noon, thus the productivity increases [17-18]. But the reduction of tilt angle lower than a specific 
limit, may be some drops will fall into the basin which leads to productivity reduction.

Figs. (2-6) also, show the variation of outer glass surface temperature with the hour of the day, it can be seen that the glass temperature increases with the day hours until it reach to the maximum values during the time period from $13 \mathrm{pm}$ to $15 \mathrm{pm}$.

The water collection is found to be increased by an average of $32 \%$ on decreasing the tilt angle from $50^{\circ}$ to $20^{\circ}$ at different depths of water in the still basin.

Figs. (7-11) show the influence of water depth in the basin on the water collection at a certain tilt angle. It was noticed that as the water depth increases, the water collection decreases. This is due to the increase of the heat capacity of the water with increasing depth, that is mean, the water needs more energy to be vaporized, which leading to lower evaporation rate [19]. The increase of water depth from $1 \mathrm{~cm}$ to $7 \mathrm{~cm}$ decreased the water collection by $30.3 \%, 32.4 \%, 30.4 \%, 34,4 \%$ and $35 \%$ for tilt angle of $20^{\circ}$ (SS No.1), $20^{\circ}$ (SS No.2), $31^{\circ}, 45^{\circ}$ and $50^{\circ}$ respectively. This behavior is owing to the reduction of the internal convective heat transfer coefficient with increasing of water depth [20]. It is observed from the experiments that a solar still with $1 \mathrm{~cm}$ water depth will start producing earlier than the others of greater water depth and at a higher rate through the daylight periods, but the productivity reduces significantly after 6:00 pm. This behavior is in agreement with the theoretical model reported by Malik et al. [21] and experimental investigation by Nafey et al. [17].

The initial productivity values at the first hours of the morning show that the distilled water productivity increases with depth, due to high temperature of the water inside the still basin at last hours of the daylight, which leads to continuous production after sunset and during the night [22].

For all solar stills, during the period from sunset at 7:00 pm until the morning of the next day, the nocturnal collected water is increased from $85(\mathrm{ml})$ to $135(\mathrm{ml})$ when the water depth is increased from 1 to $7 \mathrm{~cm}$, respectively. Hence, the night production contributed to $17.2 \%, 18.5 \%, 24 \%, 27.5 \%$ and $35.5 \%$ of the daily output at water depth of 1, 2, 3, 5 and 7 cm respectively for SS No.1. But for SS No.2 which has the same inclination angle of SS No.1 but with bigger volume, the nocturnal productivity contributed to $18.4 \%, 20 \%$, $25.8 \%, 30.3 \%$ and $39 \%$ of the daily collected water amount at the previously mentioned water depths. The reason of this increasing belong to the increasing of water heat capacity by increasing of water depth, as well as increasing of the basin volume leads to increasing the difference in temperature between the water surface and the solar still cover. Then the convective and evaporative heat transfer increased from water surface to glass lid [23]. Same behavior found for all other stills, where the contribution increases to $44.6 \%$ for basin with tilt angle of $50^{\circ}$ at $7 \mathrm{~cm}$ water depth.

It has been verified that the increase of water depth in the still basin reduces still productivity. The current study showed influenced the productivity of single slope solar stills by the water depth by percentages ranging from 30\%-35\% for water depth ranging from $1-7 \mathrm{~cm}$ respectively.

The maximum hourly amount of the yield potable water is at noon and the daily accumulated drinkable water is about 1980, 1960, 1800, 1640 and $1520 \mathrm{ml}$ per meter squared for tilt angle of $20^{\circ}$ (SS No.1), $20^{\circ}$ (SS No.2), $31^{\circ}, 45^{\circ}$ and $50^{\circ}$ respectively and water depth of $1 \mathrm{~cm}$. 


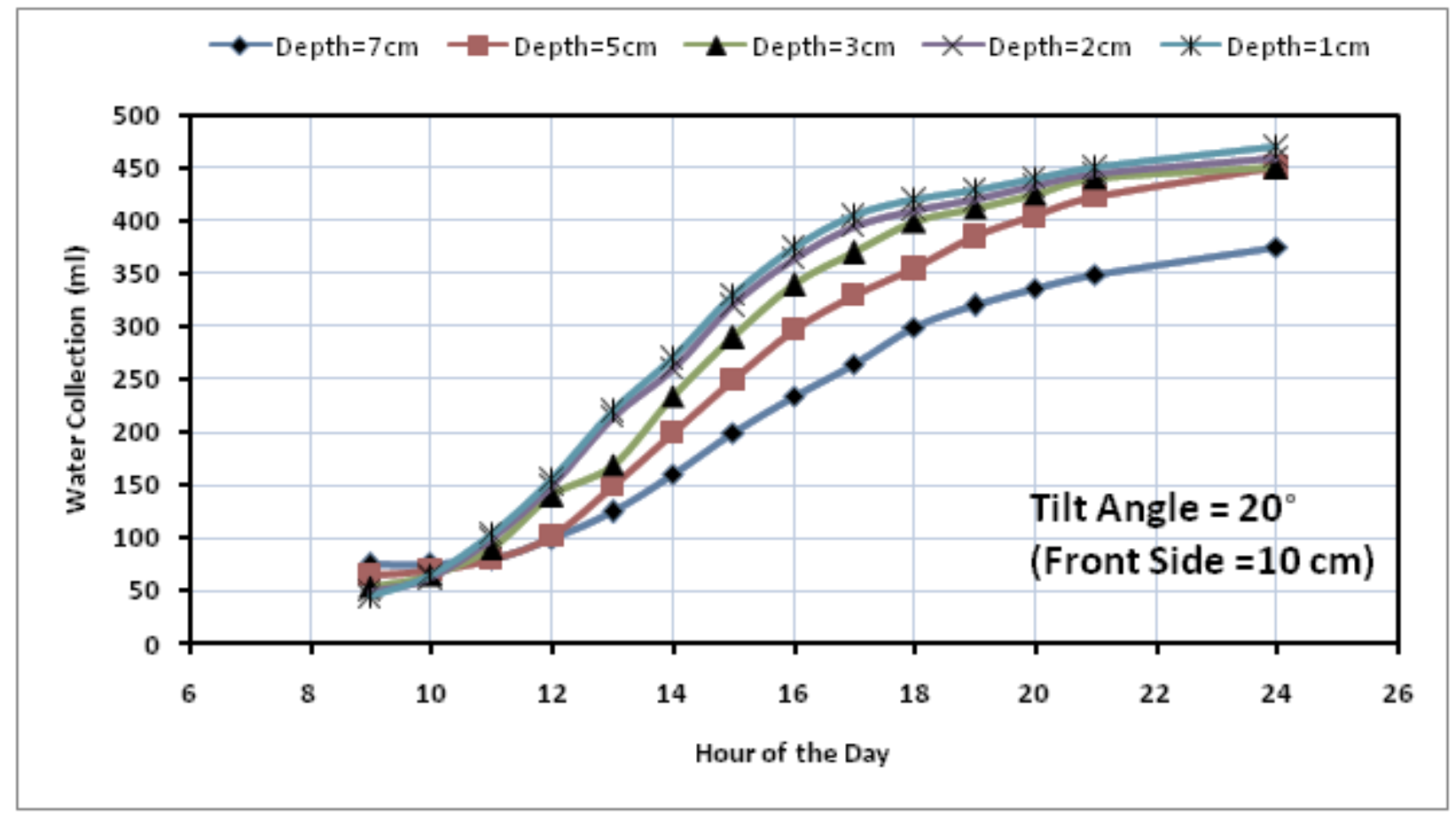

Fig.(7): Effect of water depth on hourly water collection amounts for solar still with $20^{\circ}$ tilt angle (SS No.1).

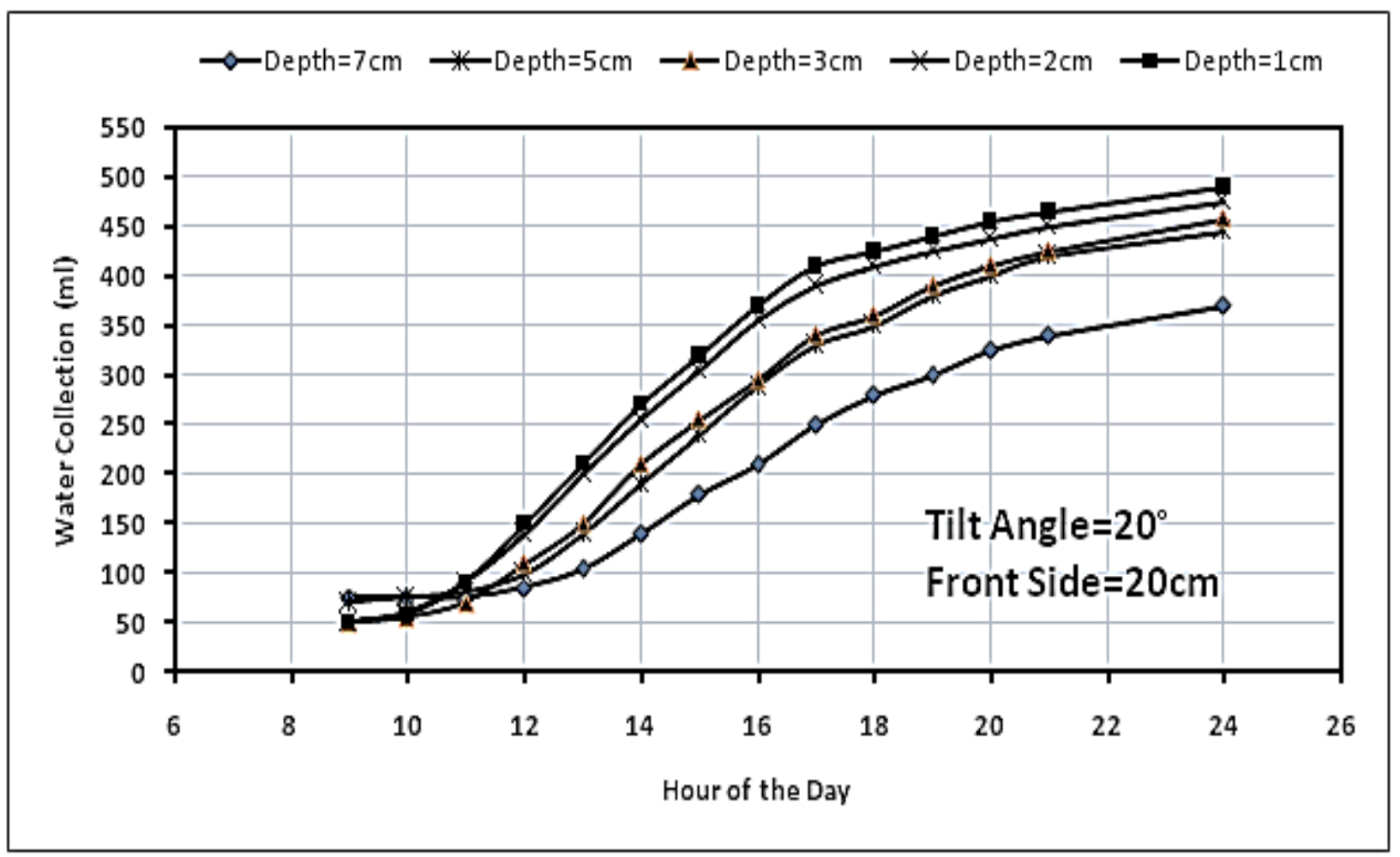

Fig.(8): Effect of water depth on hourly water collection amounts for solar still with $20^{\circ}$ tilt angle (SS No.2). 


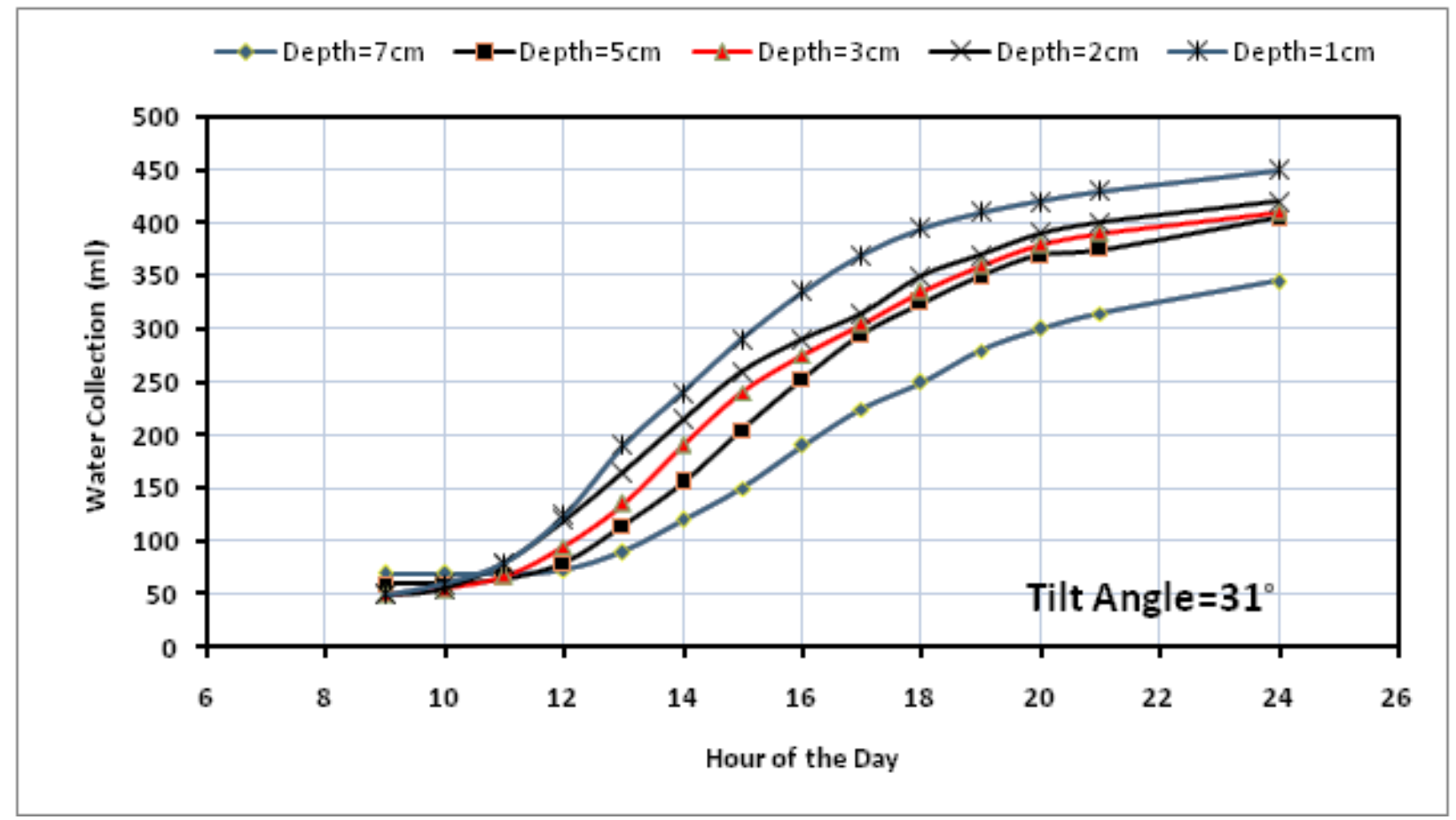

Fig.(9): Effect of water depth on hourly water collection amounts for solar still with $31^{\circ}$ tilt angle (SS No.3).

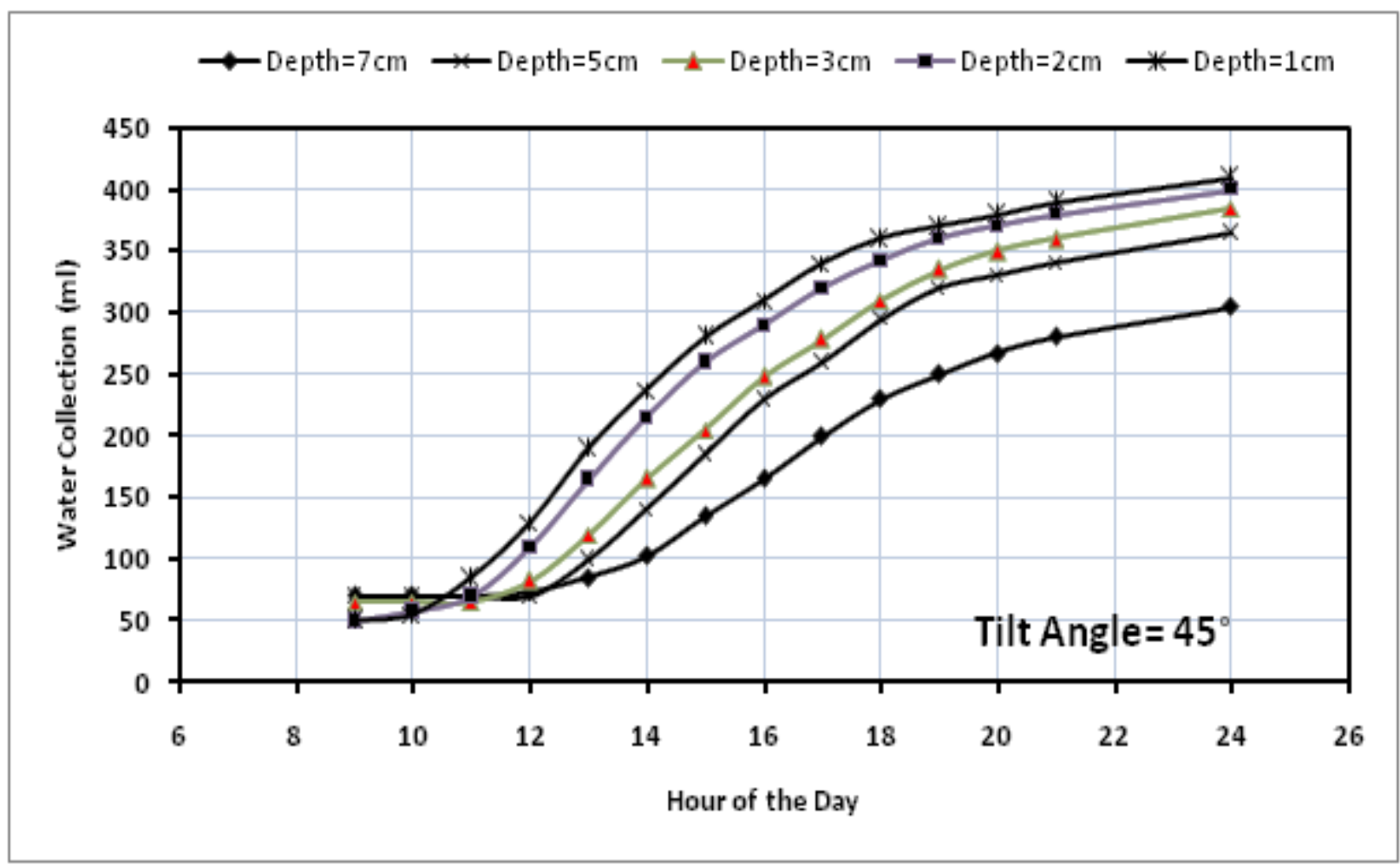

Fig.(10): Effect of water depth on hourly water collection amounts for solar still with $45^{\circ}$ tilt angle (SS No.4). 


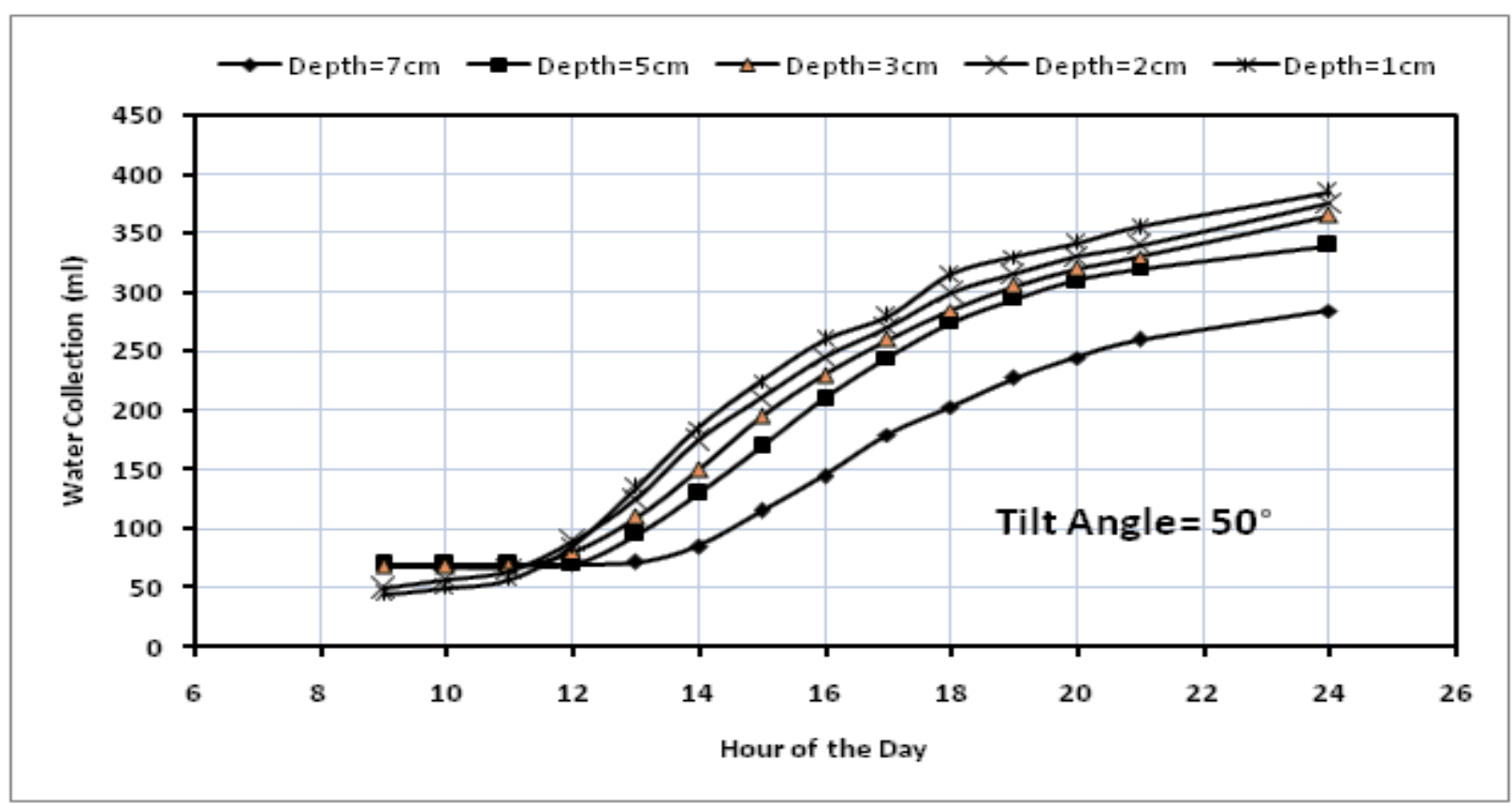

Fig.(11): Effect of water depth on hourly water collection amounts for solar still with $50^{\circ}$ tilt angle (SS No.5).

Fig.(12) summarize the result of present study. It is clear that the amount of potable water produced by using the single slope solar still affected significantly by the inclination angle and the water depth inside the solar still basin. It is evident that the daily production increases by decreasing the glass cover tilt angle and the water depth, for the reasons mentioned above.

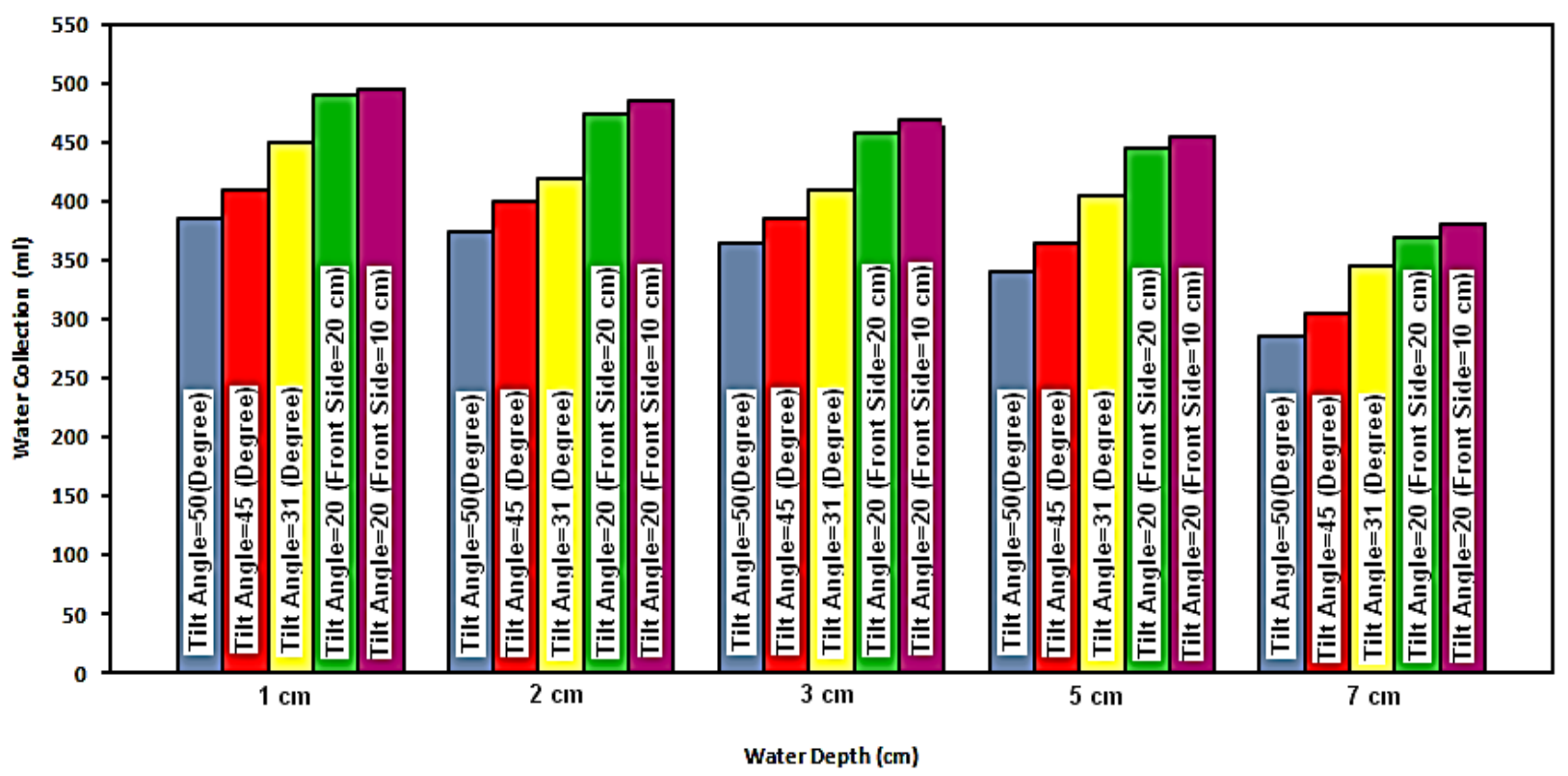

Fig.(12): Effect of tilt angle and water depth on daily water collection amount. 


\section{Conclusions}

This paper investigates the productivity of passive mode single slope solar stills. Some variables have been taken into account, including water temperature change during a day; still cover inclination angle and water depth inside the still basin. It was found the following conclusions:

1- For solar stills with the glass cover angles $20^{\circ}, 31^{\circ}, 45^{\circ}$ and $50^{\circ}$ under August weather conditions, the yield amount of fresh water increases as the cover inclination angle decreases.

2- For the glass cover angle $20^{\circ}$ (SS No.1), the water collection amount is larger than that of all other still types at different water depths.

3- A significant increase in all solar stills productivity has verified by increasing the weather temperature.

4- An important increase in potable water productivity has achieved by reducing the water depth in the still basin.

5- This study appeared that the still productivity could be affected by the water depth (1 and $7 \mathrm{~cm}$ ) by up to $30.3 \%$, $30.43 \%, 34.43 \%$ and $35.1 \%$ for basins with tilt angle of $20^{\circ}, 31^{\circ}, 45^{\circ}$ and $50^{\circ}$.

6- Also, by changing the tilt angle from $20^{\circ}$ to $50^{\circ}$, the still productivity influenced by up to $28.6 \%$ and $33.3 \%$ for water depths 1 and $7 \mathrm{~cm}$ respectively.

7- The collection water amount of the not insulated single sloped solar still with different water depth and inclination angles is averaging $450 \mathrm{ml} \mathrm{(1800}$ $\mathrm{ml} / \mathrm{day} / \mathrm{m} 2$ ).

8- Night production increases with increasing water depth and inclination angle of still cover.

\section{References}

[1] Shannon M.A., Bohn P.W., Elimelech M., Georgiadis J.G., Marinas B.J., Mayes A.M., "Science and Technology for Water Purification in the Coming Decades", Nature, 452, 301-310, 2008.

[2] Elimelech M., "The Global Challenge for Adequate and Safe Water", J. Water Supply Res. Technol. AQUA 55(1), 3-10, 2006.

[3] Kudish A. I., Evseev E. G., Walter G., Priebe T., "Simulation Study on a Solar
Desalination System Utilizing an Evaporator/Condenser Chamber", Energy Convers. Manage. 44(10), 1653-1670, 2003.

[4] Balan R., Chandrasekaran J., Shanmugan S., Janarthanan B., Kumar S., "Review on Passive Solar Distillation", Desalin. Water Treat., 28(1-3), 217-238, 2011.

[5] Gordes H. Mc. J., "Understanding solar stills", Technical Reviewers: Daniel Dunham Jacques Le Nonmand Darrell G. Phippen Published by: VITA 1600 Wilson Boulevard, Suite 500 Arlington, Virginia 22209 USA, 1985.

[6] Antar M. A., Zubair S. M., "Performance Evaluation of a Solar Still in the Eastern Province of Saudi Arabia-an Improved Analysis", Desalin. Water Treat., 22,100110, 2010.

[7] Voropoulos K., Mathioulakis E., Belessiotis V., "Experimental Investigation of the Behavior of a Solar Still Coupled with Hot Water Storage Tank", Desalination 156, 315-22, 2003.

[8] Abu-Arabi M., Zurigat Y., Al-Hinai H., Al-Hiddabi S., "Modeling and Performance Analysis of a Solar Desalination Unit with Double Glass Cover Cooling”, Desalination 143,173-82, 2002.

[9] Al-Karaghouli A. A., Alnaser W. E., "Performance of Single and Double Basin Solar-Stills", J. Appl. Energy 78(3), 347354, 2004.

[10] Khalifa AJ. N., Hamood A. M., "Effect of Insulation Thickness on the Productivity of Basin Type Solar Stills: an Experimental Verification Under Local Climate", Energy Convers. Manage. 50(9), 2457-61, 2009.

[11] Tiwari A. K, Tiwari G. N., "Effect of Water Depths on Heat and Mass Transfer in a Passive Solar Still: in Summer Climatic Condition", Desalination 195(1-3), 78-94, 2006.

[12] Khalifa AJ. N., Ali M. A., "Indoor Test on the Effect of Wind Speed on Still Performance", Int J Energy Environ. 6(3), 299-308, 2015.

[13] Nijmeh S., Odeh S., Akash B., "Experimental and Theoretical Study of a Single-Basin Solar Still in Jordan", Int. comm. Heat Mass Transfer 32, 565-572, 2005. 
[14] Bassam A. K., Abu-Hijleh, Hamzeh M., Rababa H., "Experimental Study of a Solar Still with Sponge Cubes in Basin", Energy Convers. Manage. 44(9), 1411-18, 2003.

[15] Kumar S., Tiwari G., Singh H., "Annual Performance of an Active Solar Distillation System", Desalination 127(1), 79-88, 2000.

[16] Akash B., Mohsen M., Nayfeh W., "Experimental Study of the Basin Type Solar Still Under Local Climate Conditions", Energy Convers. Manage. 41(9), 883-90, 2000.

[17] Nafey A. S., Abdel kader M., Abdelmotalip A., Mabrouk A. A., "Parameters Affecting Solar Still Productivity", Energy Convers. Manage. 41(16), 1797-809, 2000.

[18] Khalifa AJ. N., "On the Effect of Cover Tilt Angle of the Simple Solar Still on Its Productivity in Different Seasons and Latitudes", Energy Convers. Manage. 52(1), 431-436, 2011.

[19] Al Shabibi A. M., Tahat M., "Thermal Performance of a Single Slope Solar Water Still with Enhanced Solar Heating System", RE\&PQJ 1(13), 585-587, 2015.

[20] Tripathi R., Tiwari G. N., "Effect of Water Depth on Internal Heat and Mass Transfer for Active Solar Distillation", Desalination 173(2), 187-200, 2005.

[21] Malik M. A. S., Tiware G. N., Kumar A., Sodha M. S., "Active and Passive Solar Distillation: A Review In: Solar Distillation. Oxford, UK: Pergamon Press"; 1982.

[22] Khalifa AJ. N., Hamood A. M., "On the verification of the effect of water depth on the performance of basin type solar stills", Solar Energy 83, 1312-1321, 2009.

[23] Sharshir S.W., Yang N., Peng G., Kabeel A. E., "Factors Affecting Solar Stills Productivity and Improvement Techniques: a Detailed Review", Appl. Therm. Eng. 100, 267-284, 2016. 